\title{
The virulence plasmid of Salmonella dublin: detailed restriction map and analysis by transposon mutagenesis
}

\author{
Alistair J. LaX, ${ }^{*}$ Gillian D. Pullinger, G. David Baird $\dagger$ and Christine M. Williamson \\ AFRC Institute for Animal Health, Compton, Newbury, Berkshire RG16 ONN, UK
}

(Received 16 November 1989; revised 17 January 1990; accepted 31 January 1990)

\begin{abstract}
A detailed restriction map of the virulence plasmid of Salmonella dublin has been determined and used for comparison with the virulence plasmid from $S$. typhimurium. Two regions were identified which appeared to be similar based on blotting and restriction data. One, of about $22 \mathrm{~kb}$, encompassed the virulence region; the other, of about $8 \mathrm{~kb}$, was outside it. The locations of 259 transposon insertions on the S. dublin plasmid were determined and related to their effect on virulence. One gene involved in virulence but outside the essential virulence region was shown to affect citrate metabolism.
\end{abstract}

\section{Introduction}

The carriage of plasmids by Salmonella species is important for virulence. Jones et al. (1982) showed that removal of the large cryptic plasmid from $S$. typhimurium led to a reduction in mouse virulence, and similar effects have been noted for S. dublin, S. enteritidis, S. gallinarum, S. pullorum and S. choleraesuis (Terakado et al., 1983; Nakamura et al., 1985; Barrow et al., 1987; Barrow \& Lovell, 1988; Kawahara et al., 1988). It has been demonstrated that these large virulence plasmids are involved in systemic infection (Pardon et al., 1986; Manning et al., 1986) and do not affect the ability of Salmonella to cause enteric disease (Jones et al., 1988).

The plasmids carried by different serotypes differ in their size and restriction digest pattern (Popoff et al., 1984; Helmuth et al., 1985). However, plasmids from different serotypes share substantial homology in a region shown to be involved in virulence (Baird et al., 1985; Baird \& Manning, 1984; Williamson et al., 1988a ; Woodward et al., 1989). Transposon mutagenesis of the $S$. dublin and $S$. typhimurium plasmids identified some genes within this region which were involved in virulence (Baird et al., 1985; Beninger et al., 1988; Gulig \& Curtiss, 1988; Rhen et al., 1989). We and others have recently shown that a part of this region is sufficient to restore virulence to cured $S$. dublin and $S$. typhimurium isolates (Williamson et al., 1988b; Beninger et al., 1988; Gulig \& Curtiss, 1988; Norel et al., 1989a). Our work also demonstrated that regions linked to virulence lie

$\dagger$ Present address: Moredun Research Institute, Gilmerton Road, Edinburgh EH17 7JH, UK. outside the essential region (Williamson et al., 1988b).

The size of the plasmid regions involved in virulence remains unclear. This paper describes a comprehensive restriction map for the plasmid commonly found in $S$. dublin. The information was used to compare the plasmid with the $S$. typhimurium plasmid and to analyse a bank of 233 transposon-insertion mutants of $S$. dublin, each of which contained an insertion in the virulence plasmid. Several more mutants with insertions within or adjacent to the virulence region were also generated and analysed for virulence. One of these latter mutants, G19 (Williamson et al. $(1988 b)$, identified a gene located $5 \mathrm{~kb}$ outside the essential virulence region, which was shown to be involved in virulence and the ability to grow on citrate.

\section{Methods}

Strains and culture conditions. The wild-type Salmonella strains and some of the transposon-insertion mutants have already been described (Baird et al., 1985; Manning et al., 1986; Williamson et al., 1988a,b). Bacterial stocks were stored in $12 \%(\mathrm{v} / \mathrm{v})$ glycerol at $-70^{\circ} \mathrm{C}$. Bacteria were routinely grown in Luria-Bertani medium at $37^{\circ} \mathrm{C}$ (Maniatis et al., 1982).

Plasmid procedures. The rapid method of Ish-Horowitz \& Burke (1981) was used with the following modifications, which were found to be necessary for digestion of plasmid DNA from salmonellae. The bacteria were lysed at $37^{\circ} \mathrm{C}$ for $10 \mathrm{~min}$ using $5 \mathrm{mg}$ lysozyme ml ${ }^{-1}$. After incubation with $\mathrm{SDS} / \mathrm{NaOH}$ on ice for $5 \mathrm{~min}$, the mixture was incubated with sodium acetate $(3 \mathrm{M}, \mathrm{pH} 4.8)$ for $10 \mathrm{~min}$ on ice. The plasmid isolation procedures described by Baird et al. (1985) were also used.

DNA was electrophoresed in horizontal $0.6 \%$ agarose gels in Tris/acetate buffer (Maniatis et al., 1982) and fragments were isolated either by electroelution (Maniatis et al., 1982) or by absorption onto silica (Geneclean; Stratech Biotech). The restriction maps were 
constructed by a combination of single and double digests of the whole plasmid and of isolated restriction fragments. The size of fragments in the range $10-20 \mathrm{~kb}$ was assessed using the following molecular mass markers: $\lambda$ DNA cut either with $\mathrm{NaeI}$ and $\mathrm{SalI}(0 \cdot 5,12 \cdot 7,15 \cdot 2$ and $20 \mathrm{~kb})$, or with $K p n I(1.5,17.0$ and $30 \mathrm{~kb})$.

Southern blotting techniques were as described previously (Williamson et al., 1988a). The probe was prepared as follows. A plasmid preparation from $S$. typhimurium $12 / 75$ was digested with $X b a \mathrm{I}$, which cuts the plasmid once (Baird et al., 1985), and the digest was run on an agarose gel to separate the linear virulence plasmid from the small plasmid present in this isolate. The single large plasmid band was excised and the DNA was purified as above and radioactively labelled using a Multiprime kit (Amersham).

Transposon insertion mutants. Tn801 insertion mutants were prepared and their virulence was assessed as previously described (Baird et al., 1985), except where stated in the text. The new transposon insertion mutants described here were labelled M501-M590.

Transduction. Antibiotic resistance was transduced using bacteriophage P22 (HT1Aint) as described by Davis et al. (1980).

Test for ability to utilize citrate. Approximately $10^{8}$ saline-washed, exponentially growing bacteria were spread on minimal medium $\left[\mathrm{K}_{2} \mathrm{HPO}_{4}(7 \mathrm{~g}), \mathrm{KH}_{2} \mathrm{PO}_{4}(3 \mathrm{~g}), \mathrm{MgSO}_{4} .7 \mathrm{H}_{2} \mathrm{O}\right)(0 \cdot 1 \mathrm{~g}),\left(\mathrm{NH}_{4}\right)_{2} \mathrm{SO}_{4}$ $(1 \mathrm{~g})$, Noble-agar (Difco) $(20 \mathrm{~g})$, distilled water (1 litre) containing sodium citrate $(5 \mathrm{~g})$ and nicotinic acid $(0.01 \mathrm{~g})$ ). Strains able to utilize citrate grew as lawns after $48 \mathrm{~h}$ incubation at $37^{\circ} \mathrm{C}$, whereas strains unable to utilize citrate did not grow.

Assays for virulence. The virulence of wild-type and mutant strains of Salmonella for mice was assayed as described previously (Baird $e t$ al., 1985 ) using both the oral and intraperitoneal routes.

Biochemical assays. The ability of salmonellae to utilize a variety of carbohydrates was assayed using Microbact 24E kits (LIP Ltd, Shipley, West Yorkshire, UK). LPS was analysed as described previously (Williamson et al., 1988b).

\section{Results}

\section{Restriction map of the plasmid from S. dublin 2229}

The physical map of the $76 \mathrm{~kb}$ plasmid from $S$. dublin was determined for 13 enzymes (Fig. 1). The location of several of the sites around the virulence region was already known (Baird et al., 1985). The sizes of the fragments generated by each enzyme were calculated using molecular mass standards accurate for the sizes being examined, as were the sizes of the fragments produced by each enzyme in combination with $X b a \mathrm{I}$, $X h o I$ or BamHI. The fragments produced by digestion with $X h o I$ and $X b a I$ and also the largest fragment produced by digestion with $E c o$ RI were isolated from agarose gels, and subjected to single and double digests by the other enzymes. These procedures generated most of the data for the map. The relative orientations of the small EcoRI fragments were determined by mapping a bank of clones of the plasmid (Williamson, 1988). There was also evidence to suggest that there was a small fragment between $E c o$ RI fragments $\mathcal{Y}$ and D. Briefly, mapping with SacI and BamHI showed that the transposon insertions in two mutants (M513 and M587) were each located close to the junction of EcoRI fragments $C$ and $D$. However, in each case, the fragments from an $E c o$ RI digestion were the same size as fragments from the parent plasmid except that there was a new band of about $5 \cdot 3 \mathrm{~kb}$. This suggested that transposon insertion in both instances had been into an intervening fragment of about $0.3 \mathrm{~kb}$. It is possible that this putative intervening fragment was caused by an artefactual duplication linked to transposition. However, the orientation of insertion in M513 was opposite to that in M587 and it is therefore unlikely that a similar duplication could have been produced by two independent mutational events.

The correct orientation of sites that appeared very close to each other was checked by double digests of the whole plasmid or of isolated fragments. The orientations of $K p n I$ fragments $\mathrm{E}$ and $\mathrm{F}$ and of HindIII fragments $\mathrm{F}$ and I were not determined; the orientation of the latter is taken from the data of Beninger et al. (1988). Three AvrII sites were identified, but these were not mapped accurately.

A more detailed map of the virulence region was constructed for six restriction enzymes not previously mapped (AvrII, SmaI, EcoRV, PvuI, HpaI and NdeI), using a clone of the $14 \mathrm{~kb}$ SalI fragment B in pACYC184 (Fig. 2). Sites were positioned with reference to the known restriction sites in the vector (Rose, 1988) and by using double digests.

Southern blots of the $S$. dublin plasmid cut with SalI, EcoRI, SacI, HindIII, KpnI, ClaI, SfiI and SpeI were probed with the complete virulence plasmid from $S$. typhimurium. The extent of hybridization was assessed for each fragment and interpreted to show the predicted homology between the plasmids (Fig. 3). The available restriction data on $S$. typhimurium (Baird et al., 1985; A. J. Lax, unpublished) and sequence data around the position of the G19 insertion (G. D. Pullinger, unpublished) was used to define the extent of homology around the virulence region. For example, one end of this region could be defined by the absence of a SpeI site in the $S$. typhimurium plasmid and the difference in enzyme sites from this point rightwards (see Fig. 1). The other end could be defined by differences in sequence starting $700 \mathrm{bp}$ to the right of the SalI site between fragments B and $\mathrm{D}$ in the $S$. dublin plasmid and proceeding leftwards. Overall the results indicated that the homology extended from map position 59 through $76 \cdot 7 / 0$ to approximately $5 \mathrm{~kb}$. Restriction data previously obtained by Baird et al., (1985 and unpublished) indicated that there was an extra sequence of about $2 \mathrm{~kb}$ in the $S$. typhimurium plasmid which was missing in the $S$. dublin plasmid at about map position 62 (Fig. 1). In addition to the homology 

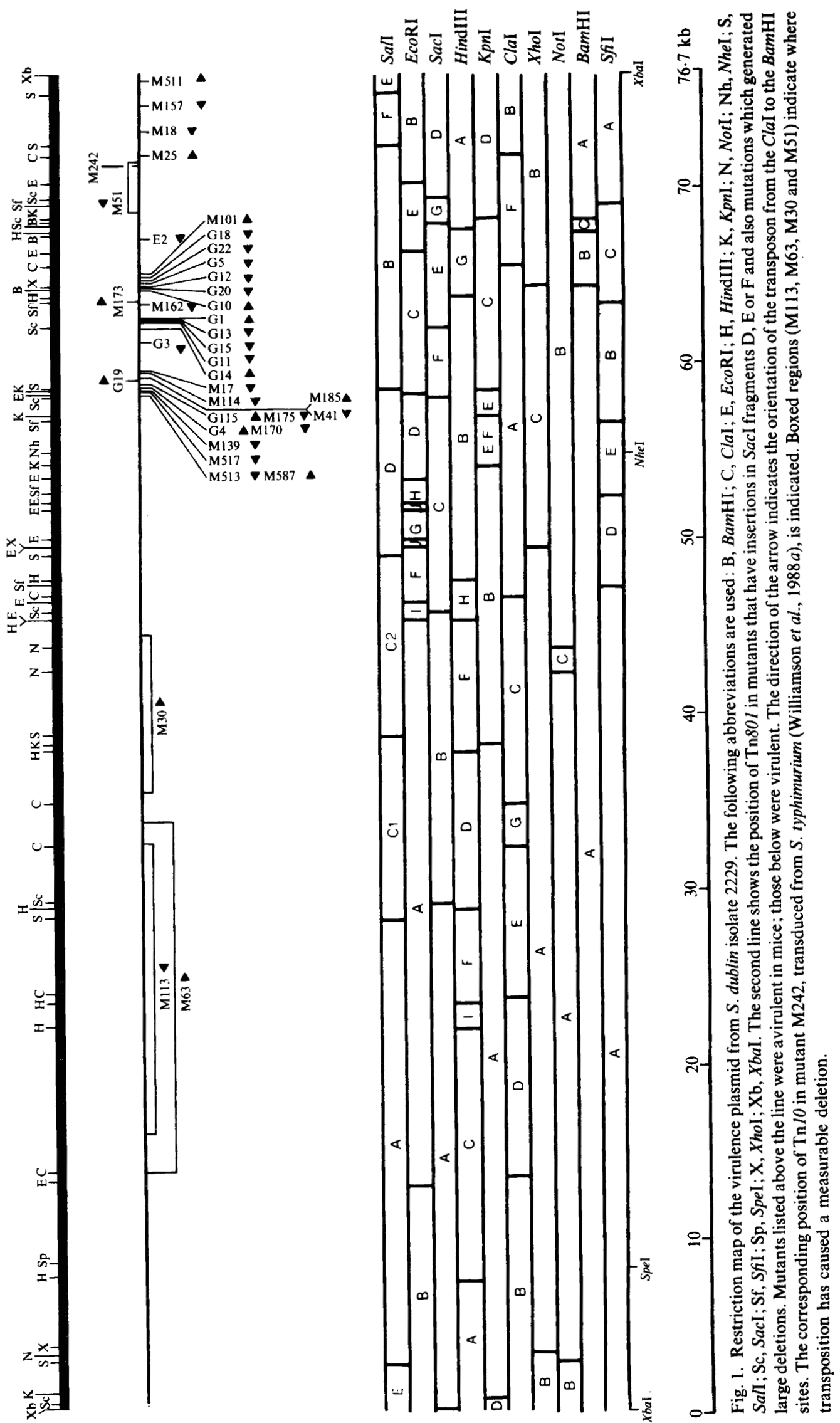


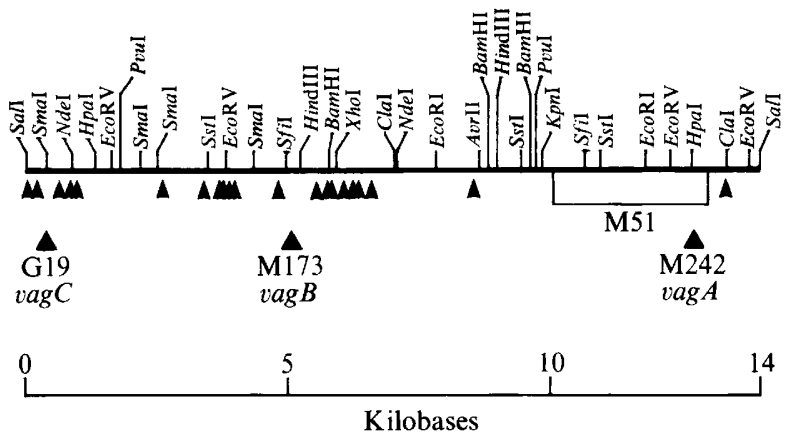

Fig. 2. Detailed restriction map of the $14 \mathrm{~kb}$ Sall fragment B from the virulence plasmid of $S$. dublin. Un-numbered arrowheads indicate sites of transposon insertion which did not affect virulence. Sites of insertion which did decrease virulence, i.e. G19, M51, M173 and M242 (site corresponding to that in the $S$. typhimurium plasmid), are also indicated. The positions of the defined virulence genes (see text) are also shown.

described above, the hybridization experiments indicated a second region of homology between about 38 and $46 \mathrm{~kb}$ (see Figs 1 and 3).

\section{Plasmid mutants}

The sites of transposon insertion in a bank of 144 virulent Tn801 insertion mutants of $S$. dublin (Baird et al., 1985) were determined by means of SacI digests. A further 89 fully virulent mutants were prepared and analysed in the same manner, and the results of both sets of mutants (prefixed $\mathrm{M}$ ) are summarized in Table 1. The mutants all contained Tn 801 inserted in the virulence plasmid. Transposition of Tn801 into the $S$. dublin virulence plasmid was non-random, as has been shown previously (Heffron et al., 1975), and which may reflect the sequence specificity of Tn801 (Tu \& Cohen, 1980).
Mutants with insertions within SacI fragments D, E or F were mapped accurately, using ClaI, BamHI and BamHI/Eco RI digests and are shown in Fig. 1. Several insertions mapped in identical positions and for simplicity only one example is shown. No insertions were found that mapped to fragment $\mathrm{G}$ (Table 1). Twelve mutants had deletions which extended from the site of insertion. The deletions in M30, M63 and M113 were mapped and are shown on Fig. 1. The mutants with a transposon insertion in SacI fragments D, E and F, and M30, M63 and $\mathrm{M} 113$, were re-tested for mouse virulence by both the oral and the intraperitoneal route and all were confirmed to be fully virulent (data not shown).

Further transposon insertions were targeted into $E c o$ RI fragments $\mathrm{C}$ and $\mathrm{E}$, using cassette mutagenesis. To achieve this, fragments $C$ and $E$ were cloned into pACYC184, and these constructs were then used to transform the cured $S$. dublin strain (M173c: Manning et al., 1986). Mutagenesis was carried out as described in Methods and ampicillin-resistant Escherichia coli were screened by EcoRI digestion of the plasmids to locate the position of insertion. The fragment sizes expected for inserts in $E c o \mathrm{RI}$ fragment $\mathrm{C}$ were either 4 and $13 \mathrm{~kb}$, or 8 and $9 \mathrm{~kb}$, depending on whether $\operatorname{Tn} 801(5 \mathrm{~kb})$ was in the insert $(8 \mathrm{~kb})$ or vector $(4 \mathrm{~kb})$. However, three bands were present in each of 18 mutants tested (Fig. 4). This implied that two different plasmid species, one containing and one without the transposon, were able to coexist in these strains.

Inserts containing a transposon were subsequently ligated into the EcoRI site of pUB307 (Bennett et al., 1977), and transformed into the semi-rough $S$. typhimurium strain, LB5010 (Williamson et al., 1988 b). Transduction of the ampicillin resistance into wild-type $S$. dublin
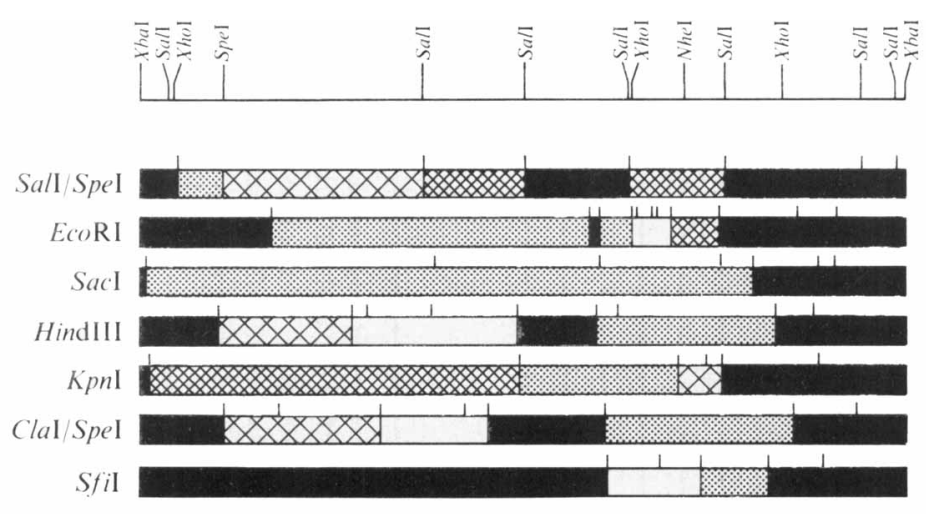

Composite

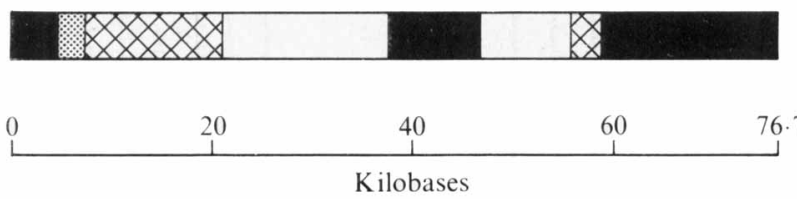

Fig. 3. Analysis of homology between the virulence plasmids of $S$. dublin and $S$. typhimurium. Southern blots of restriction digests of the $S$. dublin plasmid were probed with labelled $S$. typhimurium plasmid. The extent of hybridization for each fragment was assessed in one of five categories: very strong ( $\boldsymbol{\omega})$, strong (圆), weak (䛜), very weak ( no hybridization $(\square)$. It was not possible to determine which SalI fragment $\mathrm{C}$ hybridized, but the interpretation shown is based on the absence of hybridization to HindIII fragments $D$ and $F$. The composite interpretation was based mainly on fragments which did not hybridize, and on available restriction data (see text). 
Table 1. Location of the position of the Tn80I insertion

The SacI fragment containing Tn801 was identified for each mutant. Numbers in parentheses indicate mutants in which a deletion was found. The three mutants with deleted sites had all lost the SacI site between the A and B fragments.

\begin{tabular}{lcc}
\hline $\begin{array}{c}\text { SacI } \\
\text { fragment }\end{array}$ & $\begin{array}{c}\text { No. of } \\
\text { mutants }\end{array}$ & $\begin{array}{c}\text { Percentage } \\
\text { of total }\end{array}$ \\
\hline A & 35 & 15 \\
B & $66(5 \Delta)$ & 28 \\
C & $99(3 \Delta)$ & 43 \\
D & $6(1 \Delta)$ & 3 \\
E & 3 & 1 \\
F & 21 & 9 \\
G & 0 & 0 \\
Deleted & & 1 \\
sites & 3 & 100 \\
Total & 233 & \\
\hline \hline
\end{tabular}

2229 yielded mutants in which Tn 801 had been inserted into either EcoRI fragment $\mathrm{C}$ or $\mathrm{E}$ by homologous recombination.

Of the 26 mutants produced in this series, 25 contained Tn801 in EcoRI fragment C (prefixed G) and one contained Tn801 in EcoRI fragment E (designated E2). The locations of the insertions were determined (Fig. 1), and the mutants were tested for mouse virulence. One mutant, G19, which was briefly described by Williamson et al., (1988b), was avirulent (see below).
We have designated the genes defined by the insertions which reduce virulence as vag (for virulence associated gene). Thus vag $A$ is defined by the insertion in M242 (Pullinger et al., 1989), vagB by the insertion in M173 (Manning et al., 1986) and $v a g C$ by the insertion in G19 described here (Fig. 2).

\section{Mutant G19}

The avirulent mutant $\mathrm{G} 19$ was $10^{5}$-fold less virulent than the parental strain when inoculated by either the oral or the intraperitoneal route (results not shown). The restriction map of the plasmid from $\mathrm{G} 19$ (pG19) showed that it did not have gross deletions or other obvious differences from the parental strain. The strain was smooth with a normal LPS ladder (results not shown). pG19 was used to transform the cured strain (M173c). This strain was also smooth and avirulent.

The ability of the mutant G19 to utilize various sugars was compared to the wild-type and cured strain. The mutant lacked the ability to utilize citrate as a sole carbon source; its ability to grow on other carbohydrates (Microbact 24E) was identical to the wild-type. Although M173c could utilize citrate, introduction of pG19 led to the loss of this property, which suggested that the mutation in G19 interfered with chromosomal expression of citrate utilization.

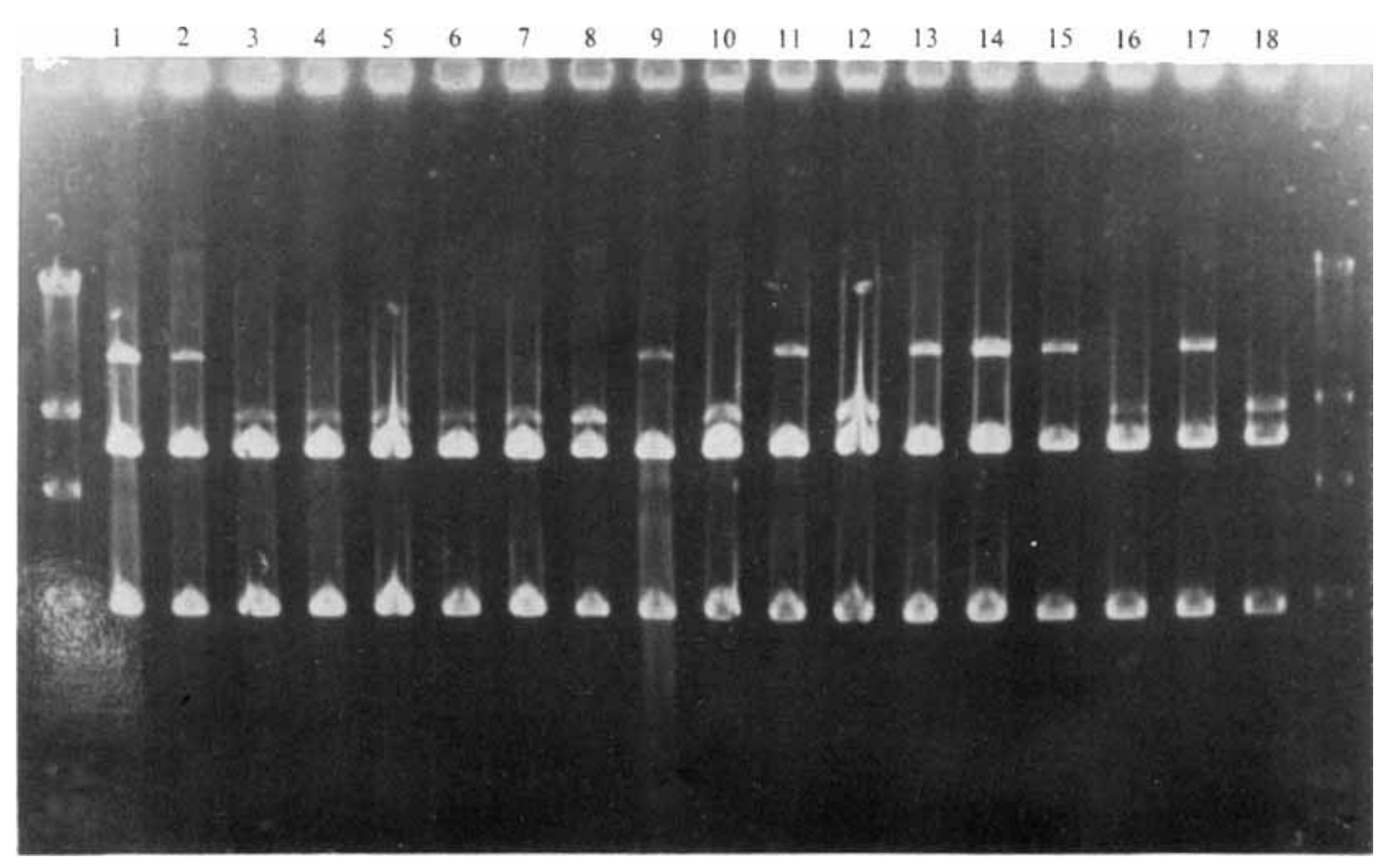

Fig. 4. EcoRI restriction digest profiles of 18 ampicillin-resistant clones containing the EcoRI fragment C inserted into pACYC184. The lanes at each side are HindIII-digested $\lambda$ DNA molecular mass markers. The mutants in lanes 1, 2, 9, 11, 13, 14, 15 and 17 have Tn801 in the insert; the others have Tn801 in the vector. 


\section{Discussion}

We describe here a detailed restriction map of the virulence plasmid commonly found in $S$. dublin isolates. Beninger et al. (1988) published a map of this plasmid based on five enzymes, in which the position of 23 sites was determined. Our map, which gives the positions of 65 enzyme sites for 13 enzymes, is in agreement with theirs, and, having more sites, makes it possible to identify and clone parts of the plasmid more easily. In addition we have constructed a detailed map of the virulence region (six more enzymes) which will aid its genetic analysis.

The $S$. dublin map showed a clustering of restriction sites which might reflect an unusual base composition and which might have some evolutionary significance. There were relatively few restriction sites for the 13 enzymes in the half of the plasmid, from position $5 \mathrm{~kb}$ to $43 \mathrm{~kb}$. Among the sites that were present those with ATrich sequences predominated. Thus, ClaI and HindIII, the only enzymes which cut more than twice within this region, both have AT-rich recognition sequences. Enzymes with CTAG within their recognition sequence cut the plasmid only rarely, which might be predicted from the low frequency of this tetranucleotide in bacterial genomes (McClelland et al., 1987). Three of these enzymes, $X b a \mathrm{I}$, NheI and SpeI, each had one site, while the other, AvrII, had three. The high number (five) of $S f i$ sites, which were clustered over a $25 \mathrm{~kb}$ stretch, was unexpected since this enzyme has an 8 bp recognition site. The $S$. typhimurium plasmid has seven Sfil sites (A. J. Lax, unpublished observations).

We produced several Tn801 insertions which did not affect virulence, and which mapped close to the insertions in the avirulent mutants G19 and M173. This indicated that the loss of virulence in G19 and M173 was probably not due to polar effects. The insertions in G19 and M173 lie outside the essential virulence region (Williamson et al., 1988b), and the target sequences for these insertions are therefore probably involved in controlling the expression of virulence (Williamson et al., $1988 b$ ). There were several differences between G19 and M173 which suggested that loss of virulence was caused by different mechanisms, perhaps indicating that vagB and vagC interact with different target genes. Mutant G19 could be complemented by the virulence region on a low-copy-number vector, whereas M173 could not (Williamson et al., 1988b). The G19, but not the M173 insertion, affected citrate metabolism, and G19 and M173 behaved differently in calf challenge experiments (Jones et al., 1988).

Transposon mapping suggested that only part of the plasmid was required for virulence, since the avirulent mutations were clustered and $27 \mathrm{~kb}$ of the plasmid could be deleted without affecting virulence (Fig. 1). This agreed with the identification of a common virulence region amongst Salmonella virulence plasmids (Williamson et al., 1988a; Woodward et al., 1989). This region has also been located by subcloning experiments (Williamson et al., 1988b; Gulig \& Curtiss, 1988; Norel et al., $1989 a$ ). We also used the $S$. dublin map to define the similarity between the $S$. dublin and $S$. typhimurium plasmids in more detail. Approximately $22 \mathrm{~kb}$ around the virulence region was very similar. There was also one other region common to both the $S$. dublin and $S$. typhimurium plasmids, but this was unlikely to be directly involved in virulence since it could be deleted (M30) without affecting virulence.

Neither the total size of the virulence region nor the number of genes involved is known. Three different genes within this region in $S$. typhimurium have recently been sequenced (vagA: Pullinger et al., 1989; mkfA: Norel et al., 1989b; mkaA: Taira \& Rhen, 1989) and there is either direct sequence evidence or protein expression data that these genes are also present in $S$. dublin (G. D. Pullinger \& A. J. Lax, unpublished observations). Although several proteins are encoded by the virulence region (Gulig \& Curtiss, 1988; Williamson, 1988; Norel et al., 1989a), their function has not been defined. We have previously shown that $8 \mathrm{~kb}$ from this region was sufficient for expression of virulence when it was present in low copy number (Williamson et al., $1988 b$ ). This suggested that some genes within it were involved in control. The sequence of one gene $(\operatorname{vag} A)$ shows significant homology with two bacterial genes, $m e t R$ and $l y s R$, which are known to be involved in regulation of gene expression (Pullinger et al., 1989). Others have identified an essential virulence region using deletions in the wild-type plasmid (Michiels et al., 1987; Beninger et al., 1988) or vectors which had comparatively low copy number (Gulig \& Curtiss, 1988). Norel et al. $(1989 a)$ restored full virulence to a cured $S$. typhimurium with a high-copy-number clone containing most of the $8 \mathrm{~kb}$ region. However, the relative contribution of the plasmid to the ability of a strain to cause systemic disease varies with different serotypes. $S$. typhimurium is less affected by the removal of its virulence plasmid than $S$. dublin or $S$. enteritidis (Williamson et al., 1988a) and there are serotypes (e.g. $S$. typhi) which do not possess virulence plasmids but cause systemic disease. There is no homology between the virulence plasmids and $S$. typhi chromosomal DNA (C. M. Williamson \& D. Maskell, unpublished observations), so there might be an alternative set of chromosomal genes which can perform a similar function. The demonstration that some plasmid genes are involved in control and apparently affect chromosomal expression suggests a possible alternative theory that the gene pro- 
ducts which enable salmonellae to survive systemically are chromosomally encoded in all serotypes and that the role of the plasmid is to control chromosomal expression. Serotypes without virulence plasmids or for which the plasmid plays a less prominent role might have circumvented these control pathways. In any event, analysis of the plasmid-encoded functions should give some insight into the way in which salmonellae survive systemically.

We thank Phil Jones and Paul Collins for many fruitful discussions.

\section{References}

BAIRD, G. D. \& MANNING, E. J. (1984). Molecular evidence for plasmid involvement in the virulence of Salmonella dublin. In Priority Aspects of Salmonellosis Research, pp. 147-153. Edited by H. E. Larsen. Brussels: Commission of the European Communities (Publication EUR 9197EN).

BaIRD, G. D., Manning, E. J. \& Jones, P. W. (1985). Evidence for related virulence sequences in plasmids of Salmonella dublin and Salmonella typhimurium. Journal of General Microbiology 131, 18151823.

Barrow, P. A. \& Lovell, M. A. (1988). The association between a large molecular mass plasmid and virulence in a strain of Salmonella pullorum. Journal of General Microbiology 134, 2307-2316.

Barrow, P. A., Simpson, J. M., Lovell, M. A. \& BinNs, M. M. (1987). Contribution of Salmonella gallinarum large plasmid toward virulence in fowl typhoid. Infection and Immunity 55, 388-392.

Beninger, P. R., Chikami, G., Tanabe, K., Roudier, C., Fierer, J. \& GuINEY, D. G. (1988). Physical and genetic mapping of the Salmonella dublin virulence plasmid pSDL2. Journal of Clinical Investigation 81, 1341-1347.

Bennett, P. M., Grinsted, J. \& Richmond, M. H. (1977). Transposition of $\operatorname{Tn} A$ does not generate deletions. Molecular and General Genetics 154, 205-212.

DAvis, R. W., Botstein, D. \& Roth, J. R. (1980). Advanced Bacterial Genetics. Cold Spring Harbor, NY: Cold Spring Harbor Laboratory.

Gulig, P. A. \& CURTISs, R., III (1988). Cloning and transposon insertion mutagenesis of virulence genes of the 100-kilobase plasmid of Salmonella typhimurium. Infection and Immunity 56, 3262-3271.

HefFron, F., RuBENS, C. \& FalKow, S. (1975). Translocation of a plasmid DNA sequence which mediates ampicillin resistance: molecular nature and specificity of insertion. Proceedings of the National Academy of Sciences of the United States of America 72, 3623-3627.

Helmuth, R., Stephen, R., Bunge, C., Hoog, B., Steinbeck, A. \& Bulling, E. (1985). Epidemiology of virulence-associated plasmids and outer membrane protein patterns within seven common Salmonella serotypes. Infection and Immunity 48, 175-182.

Ish-HorowITZ, D. \& BURKE, J. F. (1981). Rapid and efficient cosmid cloning. Nucleic Acids Research 9, 2989-2998.

JoNes, G. W., RaberT, D. K., Svinarich, D. M. \& Whitfield, H. J. (1982). Association of adhesive, invasive and virulent phenotypes of Salmonella typhimurium with autonomous 60-megadalton plasmids. Infection and Immunity 38, 476-486.

JONES, P. W., Collins, P. \& LAX, A. (1988). The role of large plasmids in the pathogenesis of salmonellosis in cattle. Journal of Medical Microbiology 27, x.

KaWahara, K., Haraguchi, Y., Tsuchimoto, M., Terakado, N. \& DANBARA, H. (1988). Evidence of correlation between 50-kilobase plasmid of Salmonella choleraesuis and its virulence. Microbial Pathogenesis 4, 155-163.

Maniatis, T., Fritsch, E. F. \& Sambrook, J. (1982). Molecular Cloning, a Laboratory Manual. New York: Cold Spring Harbor Laboratory.

Manning, E. J., Baird, G. D. \& Jones, P. W. (1986). The role of plasmid genes in the pathogenicity of Salmonella dublin. Journal of Medical Microbiology 21, 239-243.

McClelland, M., Jones, R., Patel, Y. \& Nelson, M. (1987). Restriction endonucleases for pulse field mapping of bacterial genomes. Nucleic Acids Research 15, 5985-6005.

Michiels, T., Popoff, M. Y., Durviaux, S., Coynault, C. \& CoRnelis, G. (1987). A new method for the physical and genetic mapping of large plasmids: application to the localisation of the virulence determinants on the $90 \mathrm{kbp}$ plasmid of Salmonella typhimurium. Microbial Pathogenesis 3, 109-116.

Nakamura, M., Sato, S., Ohya, T., Suzuki, S. \& Ikeda, S. (1985). Possible relationship of a 36-megadalton Salmonella enteritidis plasmid to virulence in mice. Infection and Immunity 47, 831-833.

Norel, F., Coynault, C., Miras, I., Hermant, D. \& Popoff, M. Y. $(1989 a)$. Cloning and expression of plasmid DNA sequences involved in Salmonella serotype typhimurium virulence. Molecular Microbiology 3, 733-743.

Norel, F., Pisano, M.-R., Nicoli, J. \& Popoff, M. Y. (1989b) Nucleotide sequence of the plasmid-borne virulence gene $m k f A$ encoding a $28 \mathrm{kDa}$ polypeptide from Salmonella typhimurium. Research in Microbiology 140, 263-265.

Pardon, P., Popoff, M. Y., Coynault, C., Marly, J. \& Miras, I. (1986). Virulence-associated plasmids of Salmonella serotype typhimurium in experimental murine infection. Annales de l'Institut Pasteur/Microbiologie 137B, 47-60

Popoff, M. Y., Miras, I., Coynault, C., Lasselin, C. \& Pardon, P. (1984). Molecular relationships between virulence plasmids of Salmonella serotypes typhimurium and dublin and large plasmids of other Salmonella serotypes. Anniales de l'Institut Pasteur/Microbiologie 135A, 389-398.

Pullinger, G. D., Baird, G. D., Williamson, C. M. \& LaX, A. J. (1989). Nucleotide sequence of a plasmid gene involved in the virulence of salmonellas. Nucleic Acids Research 17, 7983

Rhen, M., Virtanen, M. \& Makela, P. H. (1989). Localisation by insertional mutagenesis of a virulence-associated region on the Salmonella typhimurium 96 kilobase pair plasmid. Microbial Pathogenesis 6, 153-158.

Rose, R. E. (1988). The nucleotide sequence of pACYC184. Nucleic Acids Research 16, 355.

TAIRA, S. \& RHEN, M. (1989). Identification and genetic analysis of mkaA-a gene of the Salmonella typhimurium virulence plasmid necessary for intracellular growth. Microbial Pathogenesis 7, 165-173.

Terakado, N., Sekizaki, T., Hashimoto, K. \& Naitoh, S. (1983). Correlation between the presence of a fifty-megadalton plasmid in Salmonella dublin and virulence for mice. Infection and Immunity 41 , 443-444.

Tu, C. P. \& CoHEN, S. N. (1980). Translocation specificity of the Tn3 element: characterization of sites of multiple insertions. Cell 19, 151160 .

Williamson, C. M. (1988). Plasmid involvement in the virulence of Salmonella bacteria. $\mathrm{PhD}$ thesis, University of Reading.

Williamson, C. M., Baird, G. D. \& Manning, E. J. (1988a). A common virulence region on plasmids from eleven serotypes of Salmonella. Journal of General Microbiology 134, 975-982.

Williamson, C. M., Pullinger, G. D. \& LaX, A. J. (1988b). Identification of an essential virulence region on Salmonella plasmids. Microbial Pathogenesis 5, 469-473.

Woodward, M. J., McLaren, I. \& WRay, C. (1989). Distribution of virulence plasmids within salmonellae. Journal of General Microbiology 135, 503-511. 